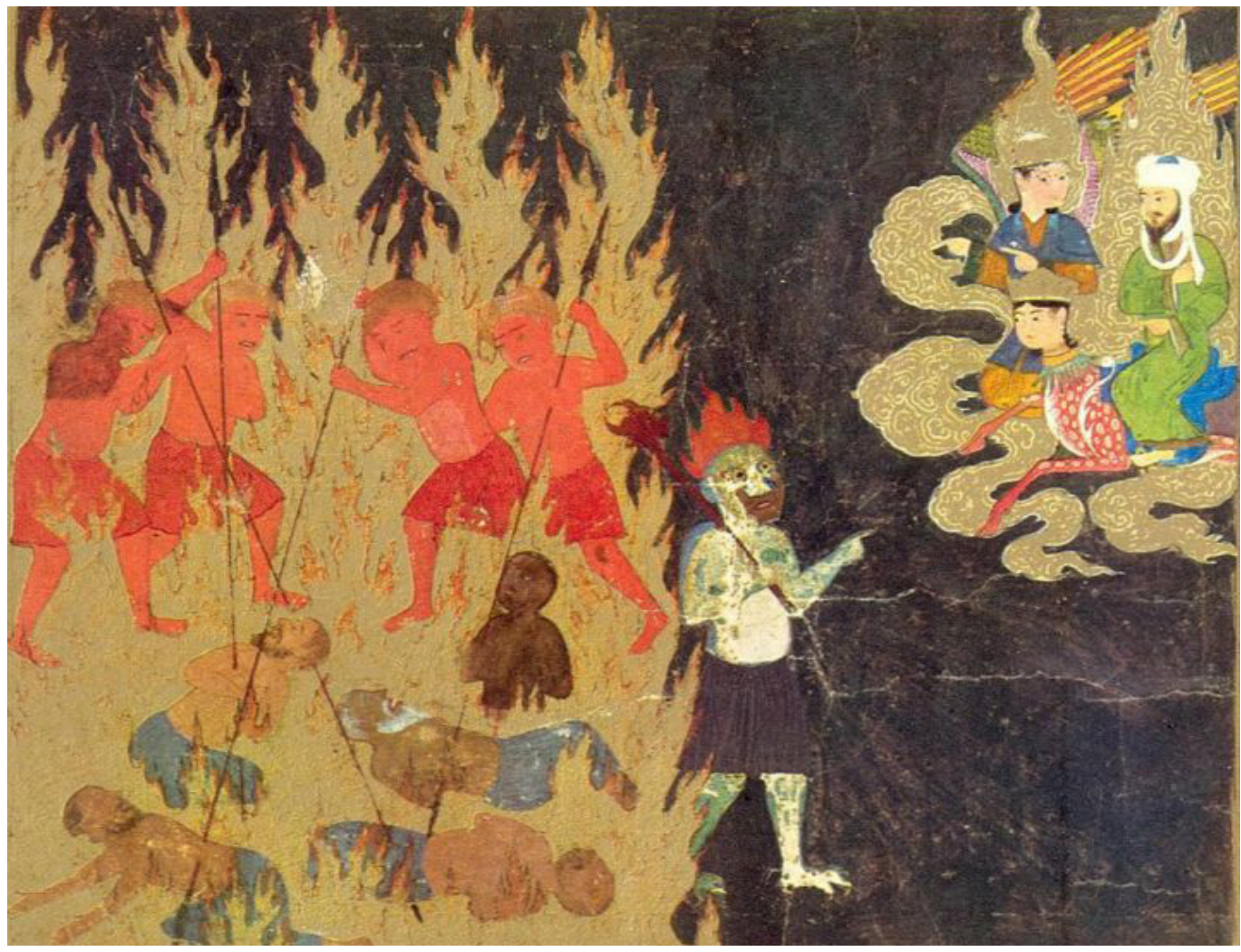

\section{Good and Bad Muslims in Xinjiang}

David BROPHY

To justify its repressive polices towards the Turkic-speaking Muslims of Xinjiang, Beijing taps into a global discourse of counterradicalisation that has developed in the context of the US-led War on Terror, a discourse that rests on the dichotomy of extremist vs. moderate Islam. Western commentary, while critical of China's policies in Xinjiang, often reflects this same way of thinking. A more effective critique will challenge the terms of this Islamophobic discourse, and the West's role in popularising it.
PC: Depiction of Islamic hell from a fifteenthcentury Turkish drawing (University of Bergen).

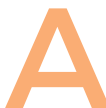

huge network of internment camps for those displaying the slightest sign of 'extremism', where, according to some ex-detainees, Muslims are encouraged to renounce their religion. Closure and demolition of mosques, with intense surveillance of those still functioning. Severe restrictions on the observance of ritual fasting, enough to dissuade all but the most devoted to the faith. These form part of the charge that the People's Republic of China (PRC) is conducting a sweeping campaign against Islam-what some activists decry as a total ban on the 
religion. For its part, China has responded with a mixture of indignation and incomprehension, with the PRC authorities maintaining that they are only following international norms of counterextremism and deradicalisation. Spokespeople for the Chinese government point to what they see as a worldwide consensus on the need to combat radicalisation through preemptive measures that identify, isolate, and rehabilitate potential extremists. A recent propaganda film on Chinese state television cites deradicalisation centres in France and Britain as precedents for China's own efforts in Xinjiang (China Central Television 2019). While Chinese experts acknowledge that the scale is different, they can explain this too: Western counterextremism policing, focussing only on select individuals, has not done enough to prevent ongoing acts of terrorism (Doyon 2019). China's more sweeping approach is not only justified, but is the logical extension of Western methods.

This is the terrain on which the war of words over the Xinjiang question is likely to be conducted for the foreseeable future, and it is worth reflecting on how best to navigate it. It may be uncomfortable to admit this, but the Chinese position has its own underlying logic. Yes, China's efforts to reengineer Islamic religious life are of a scale that seems to undermine the very foundations of the faith. But there is no denying that these policies embody a widely held view about the need to bring Islam into line with 'modern' social norms and expectations. It was Barack Obama who said in 2016 that 'some currents of Islam have not gone through a reformation that would help people adapt their religious doctrines to modernity' (Goldberg 2016). The Chinese Communist Party's (CCP) vision of a Sinicised Islam compatible with socialist modernity mirrors Obama's invocation of an idealised Christian path of religious evolution.

China's Party-state system allows for the swift implementation of an elite consensus on a mass scale, while Western liberal democracies are partly, though by no means sufficiently, constrained by civil liberties and possibilities for resistance. We should be thankful that such constraints still exist. But criticism of China's policies should not dwell on these systemic differences for too long. For those outside of China, a robust critique of China's approach, and one that provides a blueprint for an effective response, must extend to the philosophical underpinnings that its policies continue to share with the domestic War on Terror in the West. Failure to do so carries considerable risk. After all, the West's own unwillingness to confront the political causes of terrorist violence is likely to end up validating the point on which China rests its case-that the West's more circumscribed counterradicalisation strategy will fail to end terrorism. In the absence of a more radical critique that attacks the terms of this debate, China's foreign critics may well end up losing it.

\section{How the Uyghurs Became Muslims}

A heightened focus on Islam in discussions of Xinjiang-with much reporting emphasising the Muslim identity of the Uyghurs, or simply describing China as oppressing 'Muslims'-is something new. I will argue that this is justified, but we can also acknowledge extraneous factors that contribute to this framing. Outside China, freedom of religion sits alongside human rights as one of the most widely-recognised, and well-received registers of international lobbying. As Elizabeth Shakman Hurd (2015) has observed, since $9 / 11$ the institutionalisation of this discourse has led to the reinterpretation of various global conflicts in religious terms. Emphasis on the 'Muslim' identity of China's victims also provides a convenient entry point for Western actors hoping to persuade Muslimmajority countries to take a stand against China's policies. Equally, the religious identity of the Uyghurs gives the United States an opportunity to claw back some lost credibility of its own as a defender of Muslim interests. 
As Benny Avni (2018) put it in The New York Post, the Uyghurs are 'a model pro-American Muslim community'.

Some Uyghurs resent this emphasis, arguing that this is not a question of religion, but of nationality. In part, this response reflects a long-standing tendency of Uyghur intellectuals to downplay the role of Islam in Uyghur identity, and treat their predicament as the product of conflicting, even irreconcilable, national claims to the territory of Xinjiang. Concomitant with this, a generally anticommunist political orientation has often led Uyghurs to disassociate themselves from causes which pit Muslims against US imperialism, such as Palestine. Interestingly enough, such sentiments persist even among those Uyghurs drawn to jihadist militias in Syria. As reported by Gerry Shih (2017), Uyghur fighters there express admiration for Israel and how the Jews built their country'. But setting these considerations aside, the Uyghur critics seem to have a point: if China was pursuing an antiMuslim policy, then wouldn't we expect it to also sweep up the Sinophone Hui Muslims in Xinjiang? Uyghurs seem to be ending up in internment camps not because they are Muslims, but because they are Uyghurs.

This objection is best dealt with by reference to our experience in the West. Eighteen years since the launch of the War on Terror, we have become familiar with the idea of the 'racialisation' of Muslims. This is what has made it possible for police and politicians to refer to people as 'of Muslim appearance'. It has led to a spate of attacks on turbanwearing Sikhs, mistaken as Muslims by their Islamophobic assailants. The converse of this association of religious identity with visible identifying features has been the 'Islamisation' of national identity. In the wake of $9 / 11$, people have described how they came to be seen first as Muslims, and only secondly as members of a particular nationality. Self-ascription carries little weight in the face of the ability of the state and media to construct social groups.
White converts to Islam in Australia or the United States (depending on how they dress) may face little to none of the stigmatisation and discrimination directed at fellow Muslims who conform to the stereotype of the brown-skinned Muslim. Simply put, they will not be racialised as Muslim. Similarly, we might posit that in Xinjiang the Uyghurs have become racially Muslim in ways that the Sinophone Hui have not. Their Central Asian features increasingly signify the category 'Muslim', that is to say, more so than they do the category 'Uyghur', a classification which is losing its salience at administrative levels as the promises of China's minzu (民族) system-the national (or ethnic) rights enshrined in the constitution-fall by the wayside. In the more homogenous Chinese interior, of course, the situation differs. There, despite their high degree of acculturation, the communal life of the Hui singles them out as different, and we see a climate of Islamophobic suspicion growing around them. Racial and cultural distance are not things that can be measured objectively. Visible marks, or distinguishing customs, take on significance only in specific political contexts.

Thinking of the Uyghurs as racialised Muslims is compatible with analysis that emphasises the sense of a deepening racial divide in Xinjiang (e.g. Hunerven 2019), but has the advantage of allowing us to engage China's justifications for its policies on their own terms. These justifications centre not on race or ethnicity, but on extremism and terrorism-the two guiding categories of the State Council's most recent 'White Paper on Xinjiang' (State Council Information Office 2019). In the process of turning Uyghurs into racialised Muslims, the figure of the 'terrorist' clearly plays an outsized role. Chinese officialdom now describes any and all Uyghurs involved in violent actions as terrorists. In the 2009 communal riots in Ürümchi, the White Paper claims, '[t]housands of terrorists attacked civilians, government organs, public security and police officers'. In its crackdown 
since 2014, China claims to have 'arrested 12,995 terrorists'. In a global climate where the archetypal terrorist is the brown-skinned Muslim, the editorial choice to subsume any and all Uyghur violence in Xinjiang into the category of terrorism entrenches, in the most prejudicial way possible, a view of the Uyghurs as Muslims.

Superficially, China looks to be doing the exact opposite of what I am arguing. Indeed, the March 2019 White Paper goes to great lengths to downplay the Islamic identity of the Uyghurs: 'Islam is neither an indigenous belief of the Uygurs and other ethnic groups, nor the sole one of the Uygur people. Today in Xinjiang, a fairly large number of people do not believe in religion or believe in religions other than Islam.' But of course, this desire to enforce the correct line on the contingency of Islam's preeminence in Xinjiang is itself a reflection of the state's preoccupation with the Muslim identity of the Uyghurs. This insistence on the only recent and incomplete Islamisation of the Uyghurs historically has the paradoxical effect of heightening the rhetorical Islamisation of the Uyghurs in the present.

\section{China's Liberal Islamophobia}

It is possible, therefore, for an Islamophobic climate to take hold and inform policymaking, while visible marks of difference continue to shape the way that climate is experienced by different groups of Muslims. We can, and should, therefore, situate our discussion of the repression meted out to Xinjiang's Turkicspeaking minorities within an analysis of Islamophobia. That is not the only possible context for this discussion, of course, but it will be the focus of this essay.

Alongside its ongoing racial dimensions, it is important to consider the dynamics of Islamophobia itself. Islamophobia is not always expressed in the form of a blanket hostility towards Muslims. In The Muslims Are Coming!, Arun Kundnani describes how, in the wake of the War on Terror, Western anxieties surrounding Islam took on two forms. The first was a conservative discourse, which posited an incompatibility between Islam and the West-i.e. Islam as inherently backward, with Muslims predisposed to violence by virtue of their religion. The second was a liberal discourse, which set up a distinction between the 'good' Islam that can be reconciled to Western society, and the 'bad' Islam, which fosters alienation from, and hostility towards, the West. While this 'bad' Islam can act as a catalyst of radicalisation, 'good' Islam can serve as an ally against it. While ostensibly more enlightened, Kundnani shows how this liberal discourse has licensed state interventions into Muslim religious and social life that are equally, if not more, far-reaching than its conservative form.

At various points in Chinese history, the view has been expressed that Islamic customs, or theological precepts, are at some deep level incompatible with Chinese culture. In the eighteenth century, some Qing officials called on the emperor to suppress the doctrine on these grounds. The court usually repudiated such views, though they did eventually implement certain discriminatory statutes against Chinese-speaking Muslims in the interior, which reflected a view of them as particularly prone to violence. Still, even in times of conflict, it was rare for officials to attribute anti-state or anti-Han violence to any inherent flaw in the Islamic faith. While often disparaging of non-Chinese religions, China's intellectual tradition had no 'Orientalist' discourse comparable to that of the West, which furnished explanations of Muslim anti-colonial violence in terms of a congenital 'fanaticism'. To this day, Chinese analysis tends to attribute the highpoints of resistance in pre-PRC Xinjiang not to religious fervency but to the meddling of foreign imperialists. In 
a recent essay on China's western frontiers, for example, Wang Hui (2017) revives claims that a Sufi-led rebellion in the 1820 s was part of a British imperialist plot. China's March 2019 White Paper conveys a similar message in describing Republican-era Pan-Islamism as the creation of 'former colonialists'.

If one logs on to Chinese social media today, it is certainly possible to find self-styled 'Muslim-haters' (穆黑) articulating what Kundnani describes as the 'conservative' viewthat Islam is irredeemable and has no place in modern society. Much of this Chinese hate speech thrives in a pernicious feedback loop with Western online Islamophobia. Analysts such as James Leibold point out that in China's highly censored media environment, the ability of such views to circulate with relative freedom may reflect a certain connivance with them on the part of the state (Leibold 2016). At the official level, however, one is hardpressed to find Chinese pronouncements that could compare with the stridence of the West's conservative anti-Islamic rhetoric. Among candidates for the recent Australian senate elections, for example, Pauline Hanson has said that 'Islam is a disease, we need to vaccinate ourselves against that', while Fraser Anning, has called for a 'final solution' to the 'problem of Muslim immigration' (Remeikis 2017; Karp 2018).

Rather, China's official discourse on Muslims is almost exclusively of the liberal variety, drawing a dichotomy between what is acceptable and unacceptable, between 'good' and 'bad' Muslims. Chinese counterextremism experts sound exactly like their Western counterparts: they warn against Islamophobia, of the need to disassociate 'extremism' from any particular religion, and to avoid subsuming anti-extremism measures within a discourse of counterterrorism (Wang 2018). The Party's intention to 'Sinify' Islam implies a normative view of shortcomings in the religion as currently practised, but is couched in optimistic terms that posit remedies and a bright future for a healthier, more Chinese-looking version of the faith.
One way this dichotomy of 'good' and 'bad' manifests in Xinjiang today is in the divide between Turkic-speaking minorities and the Chinese-speaking Hui. This association of Xinjiang Muslims with potentially subversive foreign influences, in contrast to the more domesticated Hui, has historical precedentsbut it is worth noting that the line between 'good' and 'bad' Muslims has not always been drawn in this way. A hundred years ago, Xinjiang's Governor Yang Zengxin tended to view Hui religiosity as deviant and undesirable. He drew a contrast between what he saw as the Hui's clannish devotion to local 'Eastern' shaykhs, and the more Muhammad-centred religiosity of the Uyghurs ('devout believers in the teachings of the Western Prophet') (Brophy 2013). Writing in the shadow of the Qing Empire, Yang's views capture a moment in time before Chinese nationalism made proximity to Chinese culture a standard by which to take the measure of a citizen. And he was writing before the first of two of pro-independence uprisings in the Republican period, which led to the identification of the Uyghurs, and not the Hui, as the chief threat to Beijing's hold on Xinjiang. These twin perceptions of cultural difference and propensity for militancy now single out the Uyghurs as Xinjiang's 'bad' Muslims.

Yet importantly, the distinction applies within the Uyghur (or Kazakh, Kirghiz, etc.) community as well. The premise of the liberal view is that when 'extremist' ideology penetrates the Muslim community, it puts some, but not all of its members onto a path towards radicalisation. Descriptions of this pathway vary in the emphasis given to either theological deviations or individual psychological considerations: the two are usually hard to disentangle. From this premise an elaborate discourse has arisen, purporting to scientificity, which allows security agencies to identify 'at-risk' individuals and take steps to rehabilitate them. As other commentators have noted (e.g. Jamshidi 2019), China's lists of warning signs of radicalisation-growing a beard, donning religious dress, or even quitting smoking-immediately call to mind those 
applied in Countering Violent Extremism (CVE) policing elsewhere: Britain's Channel programme is a classic example, as is the New York Police Department's surveillance of Muslim communities in New York.

For China, the upshot of all this is something of a contradiction. On the one hand, liberal counterradicalisation theory tends to describe extremists as distorting the true meaning of Islam. This often commits the terrorism expert to a certain fundamentalism of his/ her own, and China is no exception. The task of deradicalisation, according to a Chinese scholar in Kashgar (Liu 2018), is to 'restore the basic message of the religion's teachings' (还 原宗教教义本身的主旨). On the other hand, talk of 'Sinicisation' seems to imply that Islam became something different upon reaching China and partaking of the common Chinese culture (中华文化). That is to say, Islam in China has features that distinguish it from Islam as originally conceived, and as practiced elsewhere (Zhang 2017). The intellectual gymnastics required to reconcile these two contradictory impulses will likely keep China's Islam specialists busy, but these contextual specificities should not obscure their common mission with War on Terror Islamologists in the West. The 'reformist war on terror', as Kundnani describes it, is 'one in which governments tell believers what their religion really means, and back that up with the power to criminalize alternatives' $(2014,107)$.

\section{Western Commentary on Islam in China}

Because the PRC's discourse is so enmeshed with that of the West, foreign commentary on the Chinese state's relationship to Islam often finds itself in something of a bind. While striving to be critical of China's policies, it tends to reproduce certain assumptions that drive these policies. In its most crude form, this commentary simply buys into major elements of the Chinese narrative. Although the high tide of post-9/11 counterterrorism collaboration between China and the West has receded, it has left behind a residue of low-quality punditry that more or less endorses China's claim to be fighting a serious domestic terrorist enemy. An article published by the Hoover Institute in 2018, for example, while critical of Chinese repression, describes the 'East Turkmenistan [sic] Islamic Movement' (ETIM) as 'the largest domestic extremist group in China', and parrots China's evidence-free accusations that this organisation has carried out more than 200 attacks (Auslin 2018). The author's view of 'irreconcilable tensions' here predicts a longrunning fight to the end between China and organised Uyghur terrorists.

Most writers these days are more sceptical of such claims, and critical of the Bush administration's acquiescence in deeming the nebulous ETIM as a terrorist organisation. The instinct of these commentators is to be sharply critical of China's efforts to play up the scale of the terrorist threat in Xinjiang. But at the same time, the terms of China's counterextremist discourse are so familiar, so similar to the West's own way of framing its domestic Muslim populations, that they are difficult to entirely escape. The most well-meaning critiques can easily lapse into them.

Take, for example, a recent article in The Economist on the Hui Muslims of the southwest province of Yunnan, in which the author criticises China's 'crude attempts to sinicise the faith' as counterproductive (Chaguan 2019). Holding up the example of patriotic Chinese Muslim politicians of the early-twentieth century, the author faults today's PRC officials for their ignorance of this already-existing Sinicised Islam. But then, the author encounters Hui Muslims who fail to conform to his preferred image of them. These Hui reject the hadith that 'love for the homeland is part of faith' (hubb al-watan min al-iman), thereby distancing themselves from the patriotic, Sinicised Islam that the author valorises. For this they are deemed 'historically ignorant'. What starts off as a critique of China's Sinicisation-of-Islam campaign thus 
ends up reinforcing one of this campaign's basic assumptions: that there exists a historically authentic, patriotic Chinese Islam, and that Muslims who think otherwise are getting their religion wrong.

In the case of Xinjiang, one often reads of the 'moderate, Sufi' Islam that the Uyghurs practice, usually intended as a rebuke to China's depiction of Xinjiang as a region rife with extremism. True enough, Sufism-and associated practices of shrine pilgrimage, meditation (zikr) circles, etc.-has long been an important part of religious life in Xinjiang. But these invocations carry the baggage of a distinctly Western discourse on Sufism as a meditative, new-age form of Islam, making it a perfect foil to extremist ideology. There is, in fact, little in this Western mythology surrounding Sufism that stands up to historical scrutiny. Sufis in Xinjiang have proven themselves perfectly capable of religious dogmatism, and of engaging in violence against their political enemies. It was Sufis who led the anti-Qing resistance of the nineteenth century, and judging from references to 'ishanism' (依 禅派) in early PRC accounts, it was Sufis who put up some of the stiffest resistance to the People's Liberation Army's arrival in the Tarim Basin in the 1950s (National People's Congress Ethnic Affairs Committee 1956). Criticising China's crackdown by reference to the region's Sufi traditions will likely make little sense to a Chinese audience, therefore. And more importantly, upholding the notion of a native 'moderate' Islam implies the acceptance of its converse: a foreign, non-Sufi, 'extremist' or maybe 'Salafist' Islam. This is precisely the dichotomy on which China's policies rest, and PRC officials make use of it in explaining these policies to the world. In a meeting with religious affairs officials in 2018, for example, China's ambassador to Pakistan told them that ' $\mathrm{t}$ ] he Chinese government is the bearer of Sufi and moderate thought' (Hussain 2018).

Obviously conscious of the use to which the frame of moderate Sufi vs. radical Salafist can be put, James Millward's (2019) otherwise excellent article in The New York Review of Books nonetheless relies on it, but with a twist. Instead of viewing the decline of a native Sufistic Islam and the emergence of more austere forms of religiosity as a trend arising from within the Muslim community itself, he pins the blame for this on the Chinese state: 'Chinese policies have tended to undermine indigenous Uyghur Islam and to enforce, through the partycontrolled Islamic Association of China, an idealized version of Islam modelled in part on Sunni practice as promoted by Saudi Arabia.' A better appreciation of the Xinjiang's religious traditions-something that Uyghur scholars of religion might provide-would have obviated the need for the Chinese state's misguided interventions.

Today, in its aversion to shrines and ornate mosque architecture, it is possible to see a certain convergence between Chinese policy and the prescriptions of Wahabbi Islam. Arguably, the logic behind this convergence has been present in the modernising PRC since its founding. But there is no evidence for the role of any deliberate Beijing-Saudi nexus in supplanting a shrine-centred Islam in Xinjiang. There is far more evidence to show, as we would anticipate, that scripturalism and its accompanying critique of Sufism had native roots, while also gaining sustenance from ongoing exchange between Xinjiang Muslims and the wider Islamic world, and all of this well before the Communist Revolution. Questionable from a historical point of view, Millward's narrative also keeps us firmly within the moderate/extremist paradigm, drawing a contrast between indigenous Uyghur Islam and something alien to it. Shifting the blame for a malignant Saudi-style Islam from Xinjiang Muslims themselves to the Chinese state simply does not pack the rhetorical punch it is intended to. After all, many in the West acknowledge the past role of the United States in sponsoring jihadism in Afghanistan and elsewhere, while still endorsing the need for invasive counterterror policing to root out extremist forms of Islam today. 
These are examples of ways in which analysis of Xinjiang reproduce the reformist discourse of 'good' Sufis and 'bad' scripturalists. But at times, the effort to critique China's repression in Xinjiang draws authors into something approaching the 'conservative' discourse of essential incompatibility between China and Islam. As I have discussed, this view is not a major feature of the Chinese intellectual tradition. Confucian literati could be highly disparaging of all non-Chinese faiths, but their prejudice did not lead them to envisage an inevitable showdown between China and its Muslims. This perspective, though, has had a prominent place in scholarship outside China. It emerged first in the nineteenth century, in a period of Muslim rebellions against the Qing, when the notion took hold that Islam was a rising force in China, and one that might eventually endanger Western (and Russian) interests. The discourse was revived in the 1970s, as commentators in the West became increasingly conscious of Islam as a global political force. In a 1977 article titled 'The Incompatibility between Islam and the Chinese Order', Israeli intelligence analyst-cum-historian Raphael Israeli argued that the 'Muslim presence in China ... has always posed a challenge, at times even a threat, to the Chinese establishment. This was due to [the fact] that Islam, far from willing to acculturate into Chinese society, on the contrary nurtured its distinctive traits and stressed its own superiority, something almost unheard of in other minority cultures in the Middle Kingdom' (Israeli 1977). In 1978, Harvard historian Joseph Fletcher offered a similar analysis of the Turkic-speaking Muslims of Xinjiang, arguing that they could only temporarily accept the rule of a nonMuslim emperor, and that they therefore lived under the 'obligation of jihad' (Fletcher 1978).

Today, most scholarship on Islam in China looks askance at these views, but the deteriorating situation in Xinjiang has led them to resurface, now in a more anti-CCP form. In a recent contribution, also in The New York Review of Books, Ian Johnson (2018) presents a bleak picture of the possibility for coexistence between Muslims and nonMuslims in Xinjiang. Focussing on the Qing Dynasty, he highlights what he sees as the Chinese state's inability to accommodate pluralism, manifested at that point in time in the 'Qing's Buddhist political-religious utopia', but deriving ultimately from 'older, deeper problems in the Chinese worldview'. Yet in the same article, Johnson also references Abrahamic theology's 'monolithic view of truth', a phrase which carries more than a hint that there have been cultural impediments to tolerance and coexistence on both sides. He claims that militant resistance was an immediate response to Qing rule in Xinjiang, and was motivated by the fact that Xinjiang's Muslims 'did not feel Chinese, look Chinese, speak Chinese, share Chinese values and myths and stories, or, by and large, want be part of China'.

Once again, what sets out to provide a critique of China's policies in Xinjiang ends up losing much of its force. Johnson cites historian Johan Elverskog for the view that '[w]e can't say that Islam is incompatible with China or Chinese culture.' But as he describes it, the fault line in Xinjiang ends up looking a lot like a Huntingtonian clash of civilisations. From that perspective, whether or not the Chinese state or Islam is ultimately to blame starts to become more of a question of emphasis. And regardless of where we might come down to that question, Johnson's paradigm offers little scope to think about solutions to the crisis facing Xinjiang today: if the confrontation has such deep historical and cultural roots, what can anyone hope to do about it?

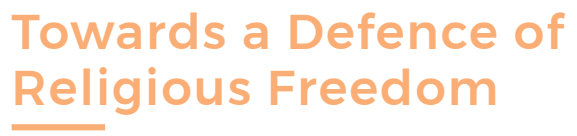

There are obviously grounds for pessimism in viewing the present state of affairs in Xinjiang. Thankfully, though, Johnson's narrative does 
not provide us with the complete picture. While the Qing Empire was merciless towards its enemies among Xinjiang's religious elite (mostly Sufis who claimed descent from the Prophet Muhammad), one can in fact tell a story of the eighteenth century as a period of considerable accommodation towards the region's Muslim population. Of course, whether or not the Qianlong reign of the high Qing provides a workable model for today's PRC is debatable. My point here is simply that history is far from univocal, and we should not allow it to dictate a particular view of the present.

On taking control of Kashgar in 1759, Qianlong immediately commissioned the restoration of the city's chief Sufi shrine. While wary of the influence that remaining members of Xinjiang's elite religious families wielded, his approach was to accommodate them in luxury in Beijing, from where they kept up contact with the Muslim society of the Tarim Basin. Johnson is correct when he writes that there was no mosque inside Beijing's Forbidden City-in his view an indication of its exclusion from the Qing's 'religious system'. But there was a mosque directly opposite, a well-appointed compound built to house this community of Xinjiang Muslims, and we know that the emperor paid it annual visits. While probably much more knowledgeable of, and interested in, Tibet's Buddhist traditions, Qianlong was equally keen to find out what Xinjiang's Muslims had to offer the dynasty in terms of spiritual capabilities, and recruited ritualists from among them to conduct rainmaking ceremonies in and around the capital. When Naqshbandi Sufi networks loyal to the dynasty's enemies were rediscovered in Xinjiang in the late eighteenth century, Qianlong's response was not to launch a bloody inquisition, but to disperse the network by appointing its members to low-ranking official positions. It was not until the 1820s, 60 years on from the Qing conquest, that dissident religious elites were able to mobilise serious resistance to the Qing, and these efforts were far from unanimously welcomed by the locals.
From Beijing's point of view, of course, all this is of secondary importance. In official rhetoric it was the arrival of 'Pan-Turkism' and 'PanIslamism' at the turn of the twentieth century that laid the foundations for today's violent extremism. But here too, history can complicate things. These twentieth-century ideologies did not automatically bring with them a critique of Chinese rule in Xinjiang, and more frequently expressed hope for anti-colonial collaboration with China. The 2019 White Paper cites Mas'ud Sabri and Muhämmämd Imin Bughra as representatives of these radicalising trends, but both men spent considerable portions of their lives working alongside Chinese nationalists in the Guomindang-hardly the $\mathrm{CV}$ we would expect from a pair of die-hard extremists. A third much-maligned villain of this period is Sabit Damulla, who served as prime minister of the short-lived East Turkistan Republic in 1933-34. Yet, although obviously inspired by 'Salafist' theology, there is nothing in his writings to indicate that he felt religiously obligated to engage in antiChinese resistance. On a trip to the Middle East in the early 1930s, Sabit Damulla penned articles describing the Muslims in Xinjiang as enjoying almost complete freedom of religion, directing most of his complaints towards the activities of European missionaries. His views were in accord with those of prominent Arab theorists of political Islam such as Rashid Rida, who held that while China lay outside the Islamic world and was technically Dar al-Harb (the Abode of War), this did not impose on Muslims any obligation to contest Chinese rule (Halevy 2019). The preferred course of action, he believed, was to engage in proselytisation of the faith.

The point to be drawn from all this is that no straight line can be drawn from theological standpoints to political prescriptions. Just as Sufism did not necessarily cultivate a pluralistic pacifism, nor was the call to return to Islam's founding texts-the Qur' an and the Hadithinvariably accompanied by a rigid antiChinese militancy. In the changing political circumstances that he encountered upon 
returning to Xinjiang, Sabit Damulla endorsed the province-wide rebellion that gave birth to the East Turkistan Republic, and justified this bid for independence in religious terms. But his participation in this act of resistance was not a function of his interpretation of Islam. The intellectual genealogy that China seeks to provide for its campaign against 'extremist ideology' cannot do the work it is designed to.

This need to separate our analysis of political violence from a typology of Islam is as true today as it has been in the past. Whether couched in terms of theological deviations, or psychologising talk of alienation and identity crisis, explanations that rely on notions of 'extremist ideology' do not provide a convincing diagnosis of the origins of terrorist violence, and therefore cannot inform effective remedies for it. Already, many experts have spoken out against the ill-founded assumptions that inform CVE policing, arguing that the empirical research on terrorism simply does not support its guiding assumptions (Ross 2016). At best these theories provide vague correlations, which count for little in the absence of more rigorous control group studies. When given voice, almost all justifications for terrorist violence centre on political grievances, which have failed to find alternative outlets for expression.

Arguing that it is political factors that spur some Uyghurs to acts of violence will provoke little objection among a Western audience predisposed to acknowledge China's policy failures. But pointing this out to China is likely to be ineffective as long as our own practices of policing Muslims obscure this basic truth. This is not to mention the prestigious, well-funded institutions that sustain the theory behind these Western policing practices, and which have contributed to disseminating a dubious counterradicalisation doctrine to China. Critics should therefore rethink the reflex calls on China to comply with international norms'. The international norms on this issue are precisely what we should be challenging. Instead, we should be working to rescue the principle of genuine religious freedom from the damage it has sustained through the global War on Terror. Muslims in China deserve the freedom to be shrine-worshipping Sufis or not, as they see fit. They should be free to insist on the exclusive validity of Islam's original texts or not, as they see fit. And if they wish to argue among themselves as to the best way of being Muslim, they should be free to do so, without the Chinese state, China's non-Muslim experts, or foreign critics intervening in that debate to pick sides, promoting preferred voices while slighting others as alien and inauthentic. To reshape the discussion in this way, we need to free ourselves from our own ingrained paradigms of good vs. bad, moderate vs. extremist Islam, which, even when invoked in a critical spirit, can serve to sustain state interventions into Muslim communities. 